\title{
Kejadian Misfile dan Duplikasi Berkas Rekam Medis Sebagai Pemicu Ketidaksinambungan Data Rekam Medis
}

\author{
Destri Karlina ${ }^{1}$, Imandini Anggimelya Putri ${ }^{2}$, Dian Budi Santoso ${ }^{3}$ \\ Program Studi D3 Rekam Medis Universitas Gadjah Mada ${ }^{1,2,3}$ \\ destrikarlina45@gmail.com ${ }^{1}$, imandinianggi@gmail.com², dianbudisantoso@gmail.com ${ }^{3}$
}

\begin{abstract}
ABSTRAK
Latar Belakang: Penelitian ini dilatarbelakangi banyaknya kejadian misfile pada saat pelayanan rawat jalan berlangsung di Puskesmas Adipala Unit I Kabupaten Cilacap. Tingkat kejadian misfie sebesar 8,15\% dan duplikasi berkas rekam medis sebesar $8,44 \%$ dari seluruh berkas rekam medis yang digunakan pada pelayanan rawat jalan. Hal tersebut mengakibatkan data pada berkas rekam medis pasien tidak berkesinambungan.

Tujuan: Penelitian ini bertujuan untuk mengetahui dan menjelaskan penyebab kejadian misfile dan duplikasi berkas rekam medis pada bagian filing Puskesmas Adipala Unit I.

Metode: Metode yang digunakan dalam penelitian ini adalah metode kualitatif dengan pendekatan fenomenologi yang dilakukan pada bulan Juni sampai dengan Juli 2016. Subjek penelitian atau informan penelitian ini terdiri dari petugas pendaftaran, filing, dan kepala TU Puskesmas Adipala Unit I yang berjumlah empat orang. Objek penelitian adalah berkas rekam medis dan pengumpulan data dilakukan dengan metode wawancara.

Hasil: Kejadian tersebut mempengaruhi tingkat kesinambungan data rekam medis di Puskesmas Adipala Unit I, yang disebabkan oleh beberapa hal ditinjau dari aspek man, method, material, machine, dan money.

Kesimpulan: Penyebab utama misfile dan duplikasi berkas rekam medis adalah regulasi yang digunakan dalam sistem penyimpanan di bagian filing. Sehingga perlu adanya pembenahan dan pembuatan kebijakan untuk menciptakan managemen rekam medis yang baik agar data dalam berkas rekam medis dapat terus berkesinambungan.
\end{abstract}

Kata kunci: penyebab misfile, kesinambungan data rekam medis, duplikasi berkas.

\begin{abstract}
Background: This study was motivated by the many misfle and duplicate of medical record document that used at the time of the service takes place. Rate of misfile was $8.15 \%$ and duplicate of medical record document was $8.44 \%$ from all of the medical record document that used in ambulatory care Those case resulted data on the patient's medical record document is not sustainable.

Objective: This study aimed to analyze the causes of the misfile incident and duplicate of medical record document on the filing division of Puskesmas Adipala Unit I.

Methods: The method used in this research is a qualitative with phenomenology study conducted during on June until July, 2016. The research subjects or informants of this study consists of admissions, filing, and the head of TU Puskesmas Adipala Unit I which amounts to four persons. The object of research is the medical record documents and data collection conducted by interview.

Results: It affects the sustainability of medical records in Puskesmas Adipala Unit I is caused by several aspects of man, method, material, machine, and money.

Conclusion: The main causes misfile and duplicate of medical record document is employing of the regulatory system on the filing storage system. Thus, the important thing is improving and policy-making to build a good medical record management for achieving sustainable medical records.
\end{abstract}

Keywords: cause misfile, sustainable medical records, duplicate of medical record document. 
Kejadian Misfile dan Duplikasi Berkas Rekam Medis...

\section{PENDAHULUAN}

Berdasarkan

PERMENKES

No.269/MENKES/PER/III/2008 rekam medis merupakan berkas yang berisikan catatan dan dokumen tentang identitas pasien, pemeriksaan, pengobatan, tindakan dan pelayanan lain yang telah diberikan kepada pasien. Keberadaan rekam medis sangat diperlukan dalam menunjang terlaksananya kegiatan pelayanan kesehatan di suatu fasilitas pelayanan kesehatan. Setiap pelayanan yang diberikan kepada pasien harus selalu tercatat pada berkas rekam medis yang bersangkutan agar tercipta kesinambungan data rekam medis. Dalam pasal 12 ayat 1 PERMENKES No.269/MENKES/PER/III/2008 tentang Rekam Medis disebutkan bahwa berkas rekam medis milik sarana pelayanan kesehatan. Artinya, sarana pelayanan kesehatan memiliki tanggung jawab penuh untuk menjaga, memelihara, dan menyediakan berkas rekam medis kembali saat dibutuhkan oleh petugas kesehatan, pasien, atau pun pihak lain pada fasilitas pelayanan kesehatan yang bersangkutan. Berkas rekam medis juga memiliki fungsi untuk melindungi petugas medis maupun non medis ketika terjadi kasus hukum. Maka dari itu, sarana pelayanan kesehatan khususnya petugas rekam medis harus bisa meminimalisir permasalahan yang terjadi di bagian rekam medis. Salah satu permasalahan yang sering terjadi yaitu missffile dan duplikasi berkas rekam medis di Puskesmas Adipala Unit I. Berikut merupakan hasil studi dokumentasi mengenai kejadian misfile dan duplikasi rekam medis di Puskesmas Adipala Unit I.

Tabel 1. Rekapitulasi Hasil Pengamatan Kejadian Misfile

\begin{tabular}{ccccc}
\hline Periode & $\begin{array}{c}\text { Jumlah } \\
\text { Misfile }\end{array}$ & $\begin{array}{c}\text { Pasien } \\
\text { Baru }\end{array}$ & $\begin{array}{c}\text { Total } \\
\text { Pasien }\end{array}$ & $\begin{array}{c}\% \\
\text { Misfile }\end{array}$ \\
\hline 15 Juni 2016 & 9 & 12 & 67 & $13,43 \%$ \\
16 Juni 2016 & 10 & 12 & 51 & $19,61 \%$ \\
17 Juni 2016 & 6 & 13 & 47 & $12,77 \%$ \\
21 Juni 2016 & 8 & 18 & 73 & $10,96 \%$ \\
22 Juni 2016 & 7 & 13 & 54 & $12,96 \%$ \\
\hline
\end{tabular}

Tabel 1. (lanjutan) Rekapitulasi Hasil Pengamatan Kejadian Misfile

\begin{tabular}{|c|c|c|c|c|}
\hline Periode & $\begin{array}{l}\text { Jumlah } \\
\text { Misfile }\end{array}$ & $\begin{array}{l}\text { Pasien } \\
\text { Baru }\end{array}$ & $\begin{array}{l}\text { Total } \\
\text { Pasien }\end{array}$ & $\begin{array}{l}\% \\
\text { Misfile }\end{array}$ \\
\hline 24 Juni 2016 & 1 & 12 & 47 & $2,13 \%$ \\
\hline 27 Juni 2016 & 6 & 35 & 94 & $6,38 \%$ \\
\hline 28 Juni 2016 & 3 & 12 & 70 & $4,29 \%$ \\
\hline 29 Juni 2016 & 4 & 26 & 55 & $7,27 \%$ \\
\hline 30 Juni 2016 & 1 & 21 & 85 & $1,18 \%$ \\
\hline 01 Juli 2016 & 2 & 20 & 56 & $3,57 \%$ \\
\hline TOTAL & 57 & 194 & 699 & $8,15 \%$ \\
\hline
\end{tabular}

Berdasarkan rekapitulasi perhitungan jumlah kejadian misfile di Puskesmas Adipala Unit I didapatkan total prosentase $8,15 \%$ dengan jumlah kejadian misfile sebanyak 57 berkas dari total 699 berkas keluar masuk saat pelayanan rawat jalan berlangsung. Jumlah kejadian misfile tertinggi terdapat pada hari kamis, 16 Juni 2016 yaitu 19,61\% dengan jumlah berkas rekam medis misfile sebanyak 10 berkas dari total 51 berkas yang digunakan. Sedangkan tingkat kejadian misfile terendah terdapat pada hari Kamis, 30 Juni 2016 yaitu 1,18\% dengan jumlah misfile sebanyak 1 berkas dari total 85 berkas yang digunakan.

Jumlah kejadian misfile pada Puskesmas Adipala Unit I dipengaruhi oleh banyaknya jumlah pasien baru. Keterkaitan tersebut bersifat berbanding terbalik. Jika jumlah pasien baru banyak, maka kejadian misfile sedikit. Hal itu dikarenakan pada pasien baru langsung dibuatkan berkas rekam medis tanpa melakukan retrival (mengambil kembali) di rak penyimpanan.

Tabel 2. Hasil pengamatan kejadian duplikasi berkas rekam medis [1]

\begin{tabular}{|c|c|c|c|}
\hline Periode & $\begin{array}{l}\text { Jumlah } \\
\text { duplikasi }\end{array}$ & $\begin{array}{l}\text { Total } \\
\text { Pasien }\end{array}$ & Prosentase \\
\hline 15 Juni 2016 & 2 & 67 & $2,99 \%$ \\
\hline 16 Juni 2016 & 8 & 51 & $15,69 \%$ \\
\hline 17 Juni 2016 & 2 & 47 & $4,26 \%$ \\
\hline 21 Juni 2016 & 1 & 73 & $1,37 \%$ \\
\hline 22 Juni 2016 & 5 & 54 & $9,26 \%$ \\
\hline 24 Juni 2016 & 3 & 47 & $6,38 \%$ \\
\hline 27 Juni 2016 & 6 & 94 & $6,38 \%$ \\
\hline 28 Juni 2016 & 1 & 70 & $1,43 \%$ \\
\hline
\end{tabular}


Kejadian Misfile dan Duplikasi Berkas Rekam Medis...

Tabel 2. (lanjutan) Hasil pengamatan kejadian duplikasi berkas rekam medis [1]

\begin{tabular}{cccc} 
Periode & $\begin{array}{c}\text { Jumlah } \\
\text { duplikasi }\end{array}$ & $\begin{array}{c}\text { Total } \\
\text { Pasien }\end{array}$ & Prosentase \\
\hline 29 Juni 2016 & 3 & 55 & $5,45 \%$ \\
30 Juni 2016 & 5 & 85 & $5,88 \%$ \\
01 Juli 2016 & 3 & 56 & $5,36 \%$ \\
\hline TOTAL & 39 & 699 & $5,58 \%$
\end{tabular}

Sumber: Data Primer

Berdasarkan rekapitulasi jumlah kejadian duplikasi berkas rekam medis di Puskesmas Adipala Unit I untuk kategori [1] (pasien mempunyai dua atau lebih berkas rekam medis dengan nomor rekam medis yang sama), didapat total prosentase yaitu $5,58 \%$ dengan total duplikasi berkas sebanyak 39 dari 699 berkas yang digunakan pada periode pengamatan. Untuk kejadian tertinggi yaitu terdapat pada periode Kamis, 16 Juni 2016 dengan total duplikasi berkas sebanyak 8 dari 51 berkas yang digunakan pada periode tersebut. Sedangkan untuk kejadian terendah yaitu terdapat pada periode Selasa, 21 Juni 2016 dengan prosentase $1,37 \%$ dengan total duplikasi berkas sebanyak 1 berkas dari 73 berkas yang digunakan pada periode tersebut.

Kejadian duplikasi berkas rekam medis di atas terjadi karena riwayat kejadian misfile yang terjadi di waktu terdahulu. Setiap kejadian misfile yang terjadi di Puskesmas Adipala Unit I, petugas langsung membuatkan berkas baru. Sehingga ketika dilakukan penyisiran saat pengembalian berkas rekam medis, petugas akan berpotensi menjumpai berkas dengan nama dan nomor rekam medis yang sama. Hal tersebut terus terjadi disebabkan tidak adanya pencatatan kejadian misfile untuk keperluan evaluasi. Tidak adanya berita acara saat terjadi misfile, membuat kejadian duplikasi berkas rekam medis semakin tidak terkontrol. Hal ini juga dilatarbelakangi karena tidak adanya perhatian khusus pada kejadian misfile dan duplikasi berkas rekam medis. Akibat dari kejadian duplikasi berkas rekam medis ini, kesinambungan data rekam medis di Puseksmas Adipala Unit I belum sepenuhnya tercapai.
Tabel 3. Hasil pengamatan kejadian duplikasi berkas rekam medis [2]

\begin{tabular}{lccc}
\hline \multicolumn{1}{c}{ Periode } & $\begin{array}{c}\text { Jumlah } \\
\text { duplikasi }\end{array}$ & $\begin{array}{c}\text { Total } \\
\text { Pasien }\end{array}$ & Prosentase \\
\hline 15 Juni 2016 & 6 & 67 & $8,96 \%$ \\
16 Juni 2016 & 0 & 51 & $0,00 \%$ \\
17 Juni 2016 & 0 & 47 & $0,00 \%$ \\
21 Juni 2016 & 0 & 73 & $0,00 \%$ \\
22 Juni 2016 & 0 & 54 & $0,00 \%$ \\
24 Juni 2016 & 1 & 47 & $2,13 \%$ \\
27 Juni 2016 & 5 & 94 & $5,32 \%$ \\
28 Juni 2016 & 1 & 70 & $1,43 \%$ \\
29 Juni 2016 & 2 & 55 & $3,64 \%$ \\
30 Juni 2016 & 3 & 85 & $3,53 \%$ \\
1 Juli 2016 & 2 & 56 & $3,57 \%$ \\
\hline TOTAL & \multicolumn{5}{c}{69} \\
\hline \multicolumn{5}{c}{ Sumber: Data Primer }
\end{tabular}

Berdasarkan rekapitulasi perhitungan jumlah duplikasi berkas rekam medis untuk kategori [2] (satu nomor rekam medis digunakan oleh banyak pasien dan banyak berkas rekam medis), didapatkan total yaitu $2,86 \%$ dengan total berkas yang terduplikasi sebanyak 20 dari 699 berkas yang digunakan pada peridoe pengamatan. Untuk prosentase tertinggi terjadi pada periode Rabu, 15 Juni 2016 yaitu 8,96\% dengan total duplikasi berkas sebanyak 6 dari 67 berkas yang digunakan pada periode tertentu. Sedangkan untuk kejadian terendah terdapat pada beberapa periode yaitu Kamis 16 Juni 2016, Jumat 17 Juni 2016, Selasa 21 Juni 2016, Rabu 22 Juni 2016 dengan prosentase 0\% yang artinya tidak ada duplikasi berkas pada periode tersebut.

Jumlah prosentase kejadian duplikasi berkas rekam medis pada kategori ini lebih sedikit dari pada sebelumnya. Karena duplikasi berkas rekam medis berupa satu nomor rekam medis yang digunakan oleh banyak pasien dan banyak berkas rekam medis, tidak dipegaruhi oleh sistem penjajaran yang ada. Seluruh nomor rekam medis sudah disediakan dalam bank nomor rekam medis di SIMPUS (Sistem Informasi Managemen Puskesmas). Sehingga satu nomor rekam medis tidak mungkin dimiliki oleh lebih dari satu berkas rekam medis. Kejadian duplikasi berkas rekam medis tersebut dapat disebabkan karena kelelahan petugas akibat beban kerja yang tinggi dengan melakukan double job yaitu di bagian 
Kejadian Misfile dan Duplikasi Berkas Rekam Medis...

pendaftaran dan bagian filing. Sehingga menyebabkan kesalahan kerja pada saat jam pelayanan, khususnya pada saat menuliskan nomor rekam medis di map berkas rekam medis.

Berdasarkan permasalahan tersebut, penelitian ini bertujuan untuk mengetahui dan menjelaskan penyebab kejadian misfile dan duplikasi berkas rekam medis beserta solusi yang bisa diterapkan untuk mengatasi permasalahan tersebut. Penelitian tentang misfile dan duplikasi berkas rekam medis dapat memberikan manfaat bagi Puskesmas yang bersangkutan untuk membenahi sistem pada unit rekam medis agar tercapai tertib administrasi serta kesinambungan data rekam medis. Selain itu, penelitian ini dapat dijadikan sebagai bahan pertimbangan untuk merancang kebijakan yang berkaitan dengan pengembangan manajemen unit rekam medis yang baik.

\section{METODE PENELITIAN}

Metode penelitian yang digunakan adalah metode kualitatif, yaitu metode yang menekankan pada deskripsi secara alami (Arikunto, 2006). Penelitian ini menggunakan pendekatan cross-sectional dimana pendekatan dilakukan dengan mengambil waktu tertentu yang relatif pendek dan pada tempat tertentu. Penelitian dilakukan selama bulan Juni - Juli 2016 bertempat di Puskesmas Adipala Unit I, Kabupaten Cilacap. Teknik pengumpulan data menggunakan observasi, wawancara dan studi dokumentasi. Observasi dilakuakan untuk mengamati tingkat kejadian misfile dan duplikasi berkas rekam medis di bagian filing. Wawancara dilakuakan kepada petugas di bagian filing dan bagian pendaftaran serta kepada Kepala Tata Usaha Puskesmas Adipala Unit I. Sementara studi dokumentasi dilakukan untuk mengumpulkan referensi yang relevan dengan topik penelitian.

Variabel yang diteliti adalah berkas rekam medis yang digunakan pasien pada saat pelayanan rawat jalan berlangsung beserta faktor lain yang berkaitan dengan kejadian misfile dan duplikasi berkas rekam medis. Cara pengambilan data dilihat menganalisa faktor dari aspek man, method, material, machine, dan money.

\section{HASIL DAN PEMBAHASAN}

Berdasarkan penelitian yang ditinjau dari beberapa aspek dalam observsi berupa man, method, material, machine, dan money beserta data kejadian misfile dan multi file, maka dijabarkan pembahasan hasil penelitian yang telah dilakukan. Terlepas dari sistem kontrol yang diterapkan dalam informasi kesehatan, terkadang berkas rekam medis terletak di lokasi yang salah atau berkas tidak dapat ditemukan (Huffman, 1994), dalam pelaksanaan rekam medis hal tersebut dikenal dengan istilah misfile. Sedangkan peneliti menjumpai dua jenis duplikasi berkas rekam medis, yaitu: [1] pasien mempunyai dua atau lebih berkas rekam medis dengan nomor rekam medis yang sama; [2] satu nomor rekam medis digunakan oleh banyak pasien dan banyak berkas rekam medis.

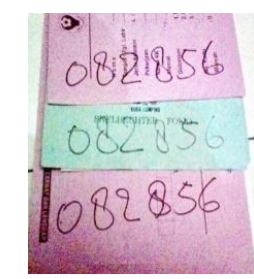

Gambar 1. Duplikasi berkas rekam medis

\section{Ditinjau dari Aspek Man}

Analisis dari aspek man, kejadian misfile dan duplikasi berkas rekam medis dapat disebabkan oleh faktor internal yang berasal dari petugas itu sendiri. Berdasarkan wawancara dengan petugas pendaftaran dan filing di Puskesmas Adipala Unit I, petugas tersebut memiliki pendidikan terakhir SMA tanpa mendapatkan pelatihan mengenai manajemen unit kerja rekam medis. Hal itu menyebabkan petugas tidak memiliki kompetensi yang harus dimiliki oleh perekam medis.

Tuntutan kompetensi tersebut diimbangi dengan adanya Kepmen Pendayagunaan Aparatur Negara (Kepmenpan) Nomor 135 tahun 2002 tentang Jabatan Fungsional Perekam Medis dan Angka Kreditnya. Kompetensi perekam medis tertera dalam Kepmenkes Nomor 377 Tahun 2007 tentang Standar Profesi Perekam Medis dan Informasi Kesehatan. Sementara itu, petugas tersebut tidak memiliki kompetensi yang berkaitan dengan kejadian misfile dan duplikasi berkas, yaitu kompetensi kedua 
berupa Aspek Hukum Rekam Medis dan Etika Profesi. Perincian dari kompetensi yang dimaksud terdapat pada point keempat yang disebutkan bahwa petugas rekam medis harus memelihara kerahasiaan informasi pasien. Sedangkan berdasarkan penelitian terhadap petugas yang bersangkutan, petugas tidak memiliki kompetensi tersebut yang dibuktikan dengan adanya pendistribusian berkas rekam medis yang dibawa sendiri oleh pasien menuju klinik.

Berdasarkan pengamatan langsung pada alur pendistribusian berkas di Puskesmas Adipala Unit I, pelaksanaan tersebut belum sesuai dengan ketentuan Depkes RI. Menurut ketentuan Depkes RI, rekam medis yang telah disiapkan akan dibawa oleh petugas rekam medis ke klinik. Petugas di bagian informasi kesehatan tidak dapat memberikan catatan medis sesuai dengan permintaan kecuali petugas yang berwenang atau orang yang ditugaskan untuk mengirim catatan medis tersebut (Huffman, 1994).

Di Puskesmas Adipala Unit I berkas rekam medis diberikan kepada pasien atau keluarga pasien kemudian pasien atau keluarga pasien akan membawa berkas rekam medis tersebut ke klinik yang dituju. Berdasarkan Permenkes 269 Tahun 2008 Pasal 10 dijelaskan bahwa berkas rekam medis harus dijaga kerahasiaannya oleh dokter, dokter gigi, tenaga kesehatan tertentu, petugas pengelola dan pimpinan sarana pelayanan kesehatan. Sehingga dengan berkas rekam medis yang dibawa pasien akan meningkatkan resiko misfile apabila berkas rekam medis tersebut tidak dijaga dengan baik oleh pembawa berkas sampai kembali ke petugas rekam medis. Penelitian lain yang mendukung adalah penelitian Hadi dkk yang menyatakan bahwa rekam medis yang dibawa sendiri oleh pasien atau keluarga pasien mempunyai resiko rekam medis akan terbawa pulang saat pasien membatalkan pelayanan kesehatannya. Selain itu, jika yang membawa bukan pasien sendiri, maka kerahasiaan rekam medis sudah tidak terlindungi.

Berdasarkan Permenkes 269 Tahun 2008 bab V tentang Kepemilikan, Pemanfaatan dan Tanggung jawab disebutkan bahwa berkas rekam medis milik sarana pelayanan kesehatan sedangkan isi rekam medis milik pasien. Isi rekam medis tidak boleh diketahui 48 atau dibaca oleh sembarang orang tanpa persetujuan pasienn ya. Selain itu berkas keluar masuk bagian filing juga tidak dilengkapi dengan buku ekspedisi, karena itulah keberadaan berkas rekam medis menjadi tidak terkontrol.

\section{Ditinjau dari Aspek Method}

Faktor kedua yaitu dari aspek method. Sistem penjajaran di ruang filing Puskesmas Adipala Unit I masih menggunakan straight numbering system. Selain memberikan kemudahan pada cara penyimpanan bagi petugas yang berlum terlatih, namun sistem ini memiliki beberapa kekurangan diantaranya: [1] persebaran berkas yang tidak merata, sehingga lebih berpotensi menyebabkan petugas akan berhimpitan ketika mengambil berkas rekam medis di areal yang sama; [2] petugas harus melihat digit nomor rekam medis secara keseluruhan sehingga menyebabkan kemungkinan terjadinya kekeliruan dalam pengambilan dan pengembalian berkas rekam medis (Budi, 2011).

Hal tersebut juga ditinjau dari beban kerja petugas yang terlalu tinggi dimana harus melakukan double job sebagai petugas filing dan pendaftaran. Berkas keluar masuk rata-rata sebanyak 64 berkas per hari dengan jam pelayanan dari pukul 07.30 sampai 11.00 WIB. Sementara petugas tetap pada bagian tersebut hanya dua orang petugas, dan satu orang kerja serabutan. Sehingga hal tersebut menimbulkan kelelahan pada petugas dan mempunyai resiko salah dalam penjajaran berkas rekam medis.

Kelelahan itu sendiri ditandai dengan penurunan efisiensi dan kebutuhan dalam bekerja (Budiono, 2003). Penelitian lain yang mendukung adalah penelitian Laxmi dkk yang menyatakan bahwa kelelahan kerja akan menurunkan kinerja petugas dalam melaksanakan tugasnya. Dapat dimungkinkan karena kurang konsentrasi menjadikan petugas salah dalam menjajarkan dokumen rekam medis sehingga terjadi misfile.

Salah satu metode yang digunakan saat menjumpai kejadian misfile adalah dengan membuatkan berkas rekam medis baru, tanpa mencatat tingkat kejadian misfile. Sehingga berkas baru tersebut dapat meningkatkan potensi terjadinya duplikasi 
berkas jika dikemudian hari ditemukan berkas dengan nomor rekam medis yang sama. Hal itu dapat menimbulkan dampak yang kurang baik pada pelaksanaan manajemen unit rekam medis. Diantaranya adalah [1] menyebabkan pemborosan dalam penggunaan formulir dan map rekam medis; [2] tidak tercapai hasil pemeriksaan yang berkesinambungan, karena terjadi duplikasi berkas dimana isi berkas tersebut terpisah. Pada point kedua berarti tidak dapat mencapai tujuan dari JCAHO (Joint Commission on Accreditation of Healthcare Organization) dalam Pedoman Akreditasi untuk Rumah Sakit, bahwa rekam medis sebagai dasar pemberian pelayanan dan evaluasi terapi yang berkesinambungan.

Berdasarkan hasil wawancara dengan kepala Tata Usaha Puskesmas Adipala Unit I, dalam pelaksanaan di bidang filing atau pun di bidang lainnya belum terdapat SPO (Standar Prosedur Operasional) yang berlaku. Prosedur kerja yang ada bersifat tidak tertulis. Menurut Kepmenpan Nomor 21 tahun 2008, SOP adalah serangkaian instruksi tertulis yang dibakukan mengenai berbagai proses penyelenggaraan administrasi pemerintah.

Sedangkan menurut Undang-undang Nomor 29 Tahun 2004, tentang Praktik Kedokteran, yang dimaksud dengan "standar prosedur operasional" adalah suatu perangkat instruksi/langkah-langkah yang dibakukan untuk menyelesaikan suatu proses kerja rutin tertentu. Standar prosedur operasional memberikan langkah yang benar dan terbaik berdasarkan konsensus bersama untuk melaksanakan berbagai kegiatan dan fungsi pelayanan yang dibuat oleh sarana pelayanan kesehatan berdasarkan standar profesi.

Berdasarkan Permenkes RI Nomor 75 Tahun 2014 tentang Puskesmas, pada Pasal 37 ayat 2, juga dijelaskan bahwa upaya kesehatan perseorangan tingkat pertama dilaksanakan sesuai dengan standar prosedur operasional dan standar pelayanan. Sehingga perlu sekali adanya SOP dalam pelaksanaan kinerja di bagian filing dan pendaftaran. Mengingat pada hari Sabtu di Puskesmas Adipala Unit I terdapat petugas piket, yang secara fungsional bukan merupakan ranah kerjanya di bagian filing dan pendaftaran.
Jika petugas yang bersangkutan tidak mengetahui tata cara pelaksanaan kerjanya di bidang filing dan pendaftaran, maka akan berpotensi meningkatkan tingkat misfile dan duplikasi berkas rekam medis. SOP sangat direkomendasikan ditempel di tempat yang mudah terlihat oleh petugas dengan tupoksi yang sesuai dengan SOP tersebut.

\section{Ditinjau dari Aspek Material}

Berdasarkan pengamatan langsung pada bagian filing Puskesmas Adipala Unit I, map yang digunakan merupakan map yang pada umumnya dijual di toko dan sebagian lagi map dengan desain terdahulu yang digunakan pada saat sistem family folder masih berlaku. Pada saat observasi, map yang digunakan tidak didesain khusus sebagai map rekam medis. Untuk melindungi halaman formulir selama masa pemeliharaan, berkas rekam medis seharusnya dilindungi dengan cover seperti chart cover, file folders, atau large envelopes (Huffman, 1994). Sementara map yang digunakan di Puskesmas Adipala Unit I tipis, lembek, dan mudah robek. Pada rak penyimpanan juga bukan merupakan rak penyimpanan khusus untuk berkas rekam medis. Rak tersebut digunakan dari bahan besi dan pada bagian tengahnya diberi sekat dari kayu yang ukurannya tidak proporsional (mudah geser).

Map yang lembek dan rak penyimpanan berkas yang tidak sesuai dengan kebutuhan menyebabkan berkas rekam medis mudah terselip dibagian yang sulit diambil, atau bahkan tidak terlihat. Pada saat kondisi petugas mengalami kelelahan kerja karena beban kerja yang tidak sesuai, motivasi kerja menurun dan berpotensi berkas tidak dapat dijangkau oleh petugas kemudian berkas dinyatakan misfile.

Dalam penelitian Putri A. P. dkk disebutkan bahwa alat yang digunakan disesuaikan dengan penggunanya dan ukuran yang dibutuhkan untuk perancangan alat kerja menggunakan data antropometri petugas filing. Sehingga perlu sekali adanya penyesuaian ukuran rak penyimpanan sesuai kebutuhan untuk mempermudah dalam melakukan retrival (mengambil kembali) maupun menjajarkan berkas rekam medis. Material lain yang tidak terdapat di bagian filing Puskesmas Adipala Unit I adalah 
Kejadian Misfile dan Duplikasi Berkas Rekam Medis...

tracer. Menurut International Federation of Health Information Management Associations (IFHIMA, 2012), tracer (outguide) yaitu pengganti rekam medis yang akan dikeluarkan dari penyimpanan untuk tujuan apapun.

Tracer digunakan untuk menelusur keberadaan rekam medis (Budi, 2010), sehingga dalam proses retrival (mengabil kembali) akan lebih cepat jika menggunakan tracer. Kendala dalam sistem penyimpan berkas rekam medis diantaranya adalah rekam medis sering terselip atau salah letak (misfile) dan hilang. Penyebab utamanya adalah pada bagian penyimpanan masih belum menggunakan tracer (outguide) untuk rekam medis yang keluar atau dipinjam (Sampurno, 2015).

\section{Ditinjau dari Aspek Machine}

Dari segi machine, Puskesmas Adipala Unit I menggunakan SIMPUS (Sistem Informasi Puskesmas) yang databasenya terpusat dalam satu Kabupaten Cilacap. Ketika melakukan observasi langsung, beberapa kali SIMPUS mengalami error dan tidak dapat bekerja sebagaimana mestinya. Hal tersebut menjadi kendala utama saat proses input data pendaftaran pasien. Dengan demikian petugas tidak dapat mencari nomor rekam medis pasien saat ada pasien yang tidak membawa KIB (Kartu Induk Berobat), karena di Puskesmas Adipala Unit I tidak terdapat KIUP (Kartu Indeks Utama Pasien) dan bergantung hanya pada database yang ada di SIMPUS.

Berdasarkan pengamatan, tindakan yang dilakuakan petugas saat SIMPUS error untuk pasien baru adalah membuat berkas rekam medis baru tanpa menggunakan map dan pada formulir rekam medis diberi tulisan error. Sedangkan pada pasien lama yang membawa KIB akan tetap dicarikan berkas rekam medisnya. Pembuatan berkas rekam medis baru dilakukan tanpa mencatatkan nama pasien yang didaftarkan pada saat SIMPUS errorserta formulir bertuliskan error tersebut tidak diarsipkan pada rak berkas rekam medis, sehingga kesinambungan data rekam medis belum bisa tercapai.

Menurut Permenkes RI Nomor 46 Tahun 2015 Tentang Akreditasi Puskesmas, Klinik Pratama, Tempat Praktik Mandiri Dokter, dan Tempat Praktik Mandiri Dokter Gigi,
SIMPUS merupakan salah satu "Penilaian Kinerja Puskesmas" dalam penilaian Akreditasi.

Mengingat Puskesmas Adipala Unit I belum terakreditasi, permasalahan pada SIMPUS tersebut sudah selayaknya menjadi perhatian khusus dalam upaya: [1] tercapainya peningkatan penilaian akreditasi; [2] tercapainya tertib administrasi dalam rangka upaya peningkatan pelayanan kesehatan; [3] tercapainya kesinambungan data rekam medis agar dapat mendokumentasikan komunikasi yang terjadi antar dokter yang bertanggung jawab memberikan pelayanan medis kepada pasien. Pada point ketiga tertera dalam tujuan JCAHO dalam Pedoman Akreditasi Rumah Sakit.

\section{Ditinjau dari Aspek Money}

Berdasarkan penyampaian Kepala Tata Usaha Puskesmas Adipala Unit I, pihak Puskesmas telah merencakan mengadaan box file untuk setiap 15-20 berkas rekam medis. Jika dilihat dari hasil observasi, penomoran berkas rekam medis di bagian filing sudah mencapai lebih dari 100.000. Jika ditinjau dari aspek money, perencanaan tersebut kurang efektif dan akan menjadikan penggelembungan rencana anggaran. Apabila satu box file berisi maksimal 20 berkas, artinya pihak Puskesmas harus menyediakan sekitar 5000 box file yang berisi berkas rekam medis. Jika satu box diasumsikan seharga Rp10.000,00, maka dibutuhkan anggaran sebesar 50 juta rupiah untuk pengadaan box file tersebut. Pihak Puskesmas mengharapkan dengan adanya pengadaan box file dapat memperbaiki sistem penyimpanan di bagian filing. Namun hal tersebut akan menyulitkan petugas dalam mengambil berkas, karena map berkas rekam medis belum didesain khusus sesuai dengan tempat penyimpanan. Meskipun penjajaran akan lebih rapih, tetapi proses retrival akan menjadi lebih lama.

Sementara untuk memenuhi tenaga rekam medis yang sesuai dengan kompetensi yang butuhkan, maka diperlukan penambahan SDM dengan kualifikasi lulusan D3 Rekam Medis. Hal itu memerlukan perencanaan anggaran untuk recruitment petugas baru. Dengan petugas yang memiliki kompetensi dan kualifikasi 
yang mumpuni, maka permasalahan yang sering terjadi di unit rekam medis seperti misfile dan duplikasi berkas rekam medis dapat mulai teratasi.

Selain faktor-faktor di atas, ada faktor lain yang cukup berpengaruh. Berdasarkan penuturan petugas di bagian filing dan pendaftaran, kesejahteraan petugas dari aspek money belum terpenuhi. Terbukti dengan keluhan petugas yang disampaikan pada saat wawancara berlangsung. Hal ini menyebabkan kurangnya motivasi petugas untuk melaksanakan pekerjaan dengan lebih baik lagi serta kurangnya motivasi untuk melakukan perbaikan manajemen rekam medis yang ada.

\section{PENUTUP}

Berdasarkaan hasil pengamatan dan pembahasan yang telah dipaparkan, dapat diambil kesimpulan bahwa: [1] kejadian duplikasi berkas sangat mempengaruhi tingkat kesinambungan data rekam medis pasien; [2] minimnya jumlah dan kompetensi SDM di bidang rekam medis menyebabkan kejadian misfile dan duplikasi berkas terus berlanjut; [3] tidak adanya SPO dalam pelaksanaan di bagian filing dan sistem penjajaran berkas menjadi salah satu penyebab yang sangat potensial pada kejadian misfile dan duplikasi berkas rekam medis [4] tidak adanya tracer (outguide) dan buku ekspedisi berkas rekam medis menyebabkan keberadaan berkas rekam medis menjadi tidak terkontrol; [5] SIMPUS di Puskesmas Adipala Unit I salah satu pemicu terjadinya ketidaksinambungan data rekam medis saat terjadi error; [6] perlu penyediaan anggaran untuk recruitment SDM dengan kompetensi dan kualifikasi dari D3 Rekam Medis.

Peneliti memberikan beberapa saran untuk Puskesmas Adipala Unit I, antara lain; [1] lakuakan cross check ke segala tempat berdasarkan alur berkas untuk memastikan keberadaan berkas rekam medis; [2] lakukan recruitment SDM dengan kompetensi dan kualifikasi dari D3 Rekam Medis, serta adakan pelatihan sesuai kebutuhan; [3] sediakan SPO (Standar Prosedur Operasional) bagi petugas yang bersangkutan dan gunakan sistem penyimpanan TDF (Terminal Digit Flling); [4] penggunaan tracer dan buku ekpedisi peminjaman berkas rekam medis; [5] lakukan upgrade SIMPUS dan sediakan SPO yang berlaku ketika SIMPUS error supaya kesinambungan berkas tetap terjamin; [6] lakukan evaluasi secara berkala dan buatkan perencanaan anggaran untuk mengatasi permasalahan yang ada jika dalam penyelesaian masalah tersebut memerlukan anggaran.

\section{DAFTAR PUSTAKA}

Arikunto, S. (2006). Prosedur Penelitian Suatu Pendekatan Praktik. Jakarta: Rineka Cipta.

Budi, S. C. (2010). Management Unit Kerja Rekam Medis. Yogyakarta: Quantum Sinergis Media.

Depkes RI. (2006). Pedoman Penyelenggaraan dan Prosedur Rekam Medis Rumah Sakit. Jakarta: Direktorat Jendral Bina Pelayanan Medik.

Huffman, Edna K. (1994). Helath Information Management. Berwyn, Illions: Physicians Record Company.

Mauludi, M.N. (2010). Faktor-faktor yang Berhubungan dengan Kelelahan pada Pekerja di Proses Produksi Kantong Semen PBD PT. Indocement Tunggal Prakarsa TBK. Skripsi. Fakultas Kedokteran dan Ilmu Kesehatan UIN Syarif Hidayatullah, Jakarta.

Putri, A. P. (2014). Analisis Tata Ruang Tempat Penyimpanan Dokumen Rekam Medis Pasien Ditinjau dari Aspek Antropometri Petugas Rekam Medis. Jurnal Manajemen Informasi Kesehatan Indonesia. 3 (1): 41-19.

Kepmenpan Republik Indonesia. (2002). Pendayagunaan Aparatur Negara (Kepmenpan) Nomor 135 Tahun 2002 tentang Jabatan Fungsional Perekam Medis dan Angka Kreditnya. Jakarta: Sekretariat Negara.

Undang-undang Republik Indonesia. (2004). Nomor 29 Tahun 2004 tentang Praktik Kedokteran. Jakarta: Sekretariat Negara.

Kepmenkes Republik Indonesia. (2007). Nomor 377 Tahun 2007 tentang Standar Profesi Perekam Medis dan Informasi Kesehatan. Jakarta: Sekretariat Negara.

Permenkes Republik Indonesia. (2008). Republik Indonesia Nomor 269 Tahun 2008 tentang Rekam Medis. Jakarta: Sekretariat Negara. 
Permenpan Republik Indonesia. (2008).

Nomor 21 Tahun 2008 tentang Pedoman

Penyusunan Standar Operating

Prosedur (SOP) Admnistrasi

Pemerintahan. Jakarta: Sekretariat

Negara.

Permenkes Republik Indonesia. (2014).

Nomor 74 Tahun 2014 tentang Pusat

Kesehatan Masyarakat. Jakarta:

Sekretariat Negara.

Permenkes Republik Indonesia. (2015).

Nomor 46 Tahun 2015 Tentang

Akreditasi Puskesmas, Klinik Pratama,

Tempat Praktik Mandiri Dokter, dan

Tempat Praktik Mandiri Dokter Gigi.

Jakarta: Sekretariat Negara.

Sampurno, Y. (2015). Desain Tracer (Outguide) di dalam Penyimpanan Berkas Rekam Medis RSIY PDHI Yogyakarta. Tugas Akhir. Rekam Medis Sekolah Vokasi UGM, Yogyakarta. 